\title{
KEDUDUKAN KURATOR DALAM MELAKUKAN EKSEKUSI BUDEL PAILIT YANG BERIMPLIKASI PADA PELAPORAN SECARA PIDANA SUATU KAJIAN UNDANG-UNDANG NO. 37 TAHUN 2004 TENTANG KEPAILITAN DAN PENUNDAAN KEWAJIBAN PEMBAYARAN UTANG
}

\author{
Ridwan \\ Mahasiswa Program Studi Magister Hukum \\ Universitas Semarang
}

\begin{abstract}
ABSTRAK
Profesi kurator mudah dikriminalisasi saat menjalankan profesinya terkait masalah kepengurusan harta budel pailit. Kasus yang menimpa Kurator Iskandar Zulkarnaen dan Ali Sumali Nugroho adalah contohya.

Permasalahan penelitian ini tentang bagaimana kedudukan kurator dalam melakukan eksekusi budel pailit yang berimplikasi pada pelaporan secara pidana dan permasalahan serta solusi yang dihadapi kurator dalam melakukan eksekusi budel pailit yang berimplikasi pada pelaporan secara pidana menurut UU Kepailitan dan PKPU. Metode pendekatan yang digunakan adalah metode penelitian yuridis normatif. Penelitian ini merupakan penelitian deskriptif analitis. Jenis data yang digunakan adalah data sekunder. Metode pengumpulan data meliputi studi kepustakaan dan studi dokumentasi yang kemudian dianalisis secara kualitatif.

Berdasarkan hasil penelitian dan pembahasan, kedudukan kurator dalam melakukan eksekusi budel pailit dapat berimplikasi pada pelaporan secara pidana jika dalam menjalankan tugasnya kurator terbukti tidak independen dan mempunyai benturan kepentingan dengan debitor atau kreditor. Ketentuan ini diatur dalam Pasal 225 ayat (2) UU Kepailitan dan PKPU. Permasalahan yang dihadapi karena Pasal 15 ayat (3) dan Pasal 234 ayat (1) UU Kepailitan dan PKPU tidak menjelaskan mengenai perbuatan tidak independen apa yang dapat menyebabkan seorang kurator dipidana. Sebagai solusinya, UU Kepailitan dan PKPU perlu menentukan kriteria tolak ukur independensi kurator. Kesimpulan penelitian ini, sebagai profesi hukum yang independen, kedudukan kurator dalam melakukan eksekusi budel pailit selain terikat pada kode etik profesi kurator juga terikat pada KUHP. Artinya, KUHP tetap dapat diberlakukan sepanjang kurator tersebut memenuhi unsur-unsur dalam tindak pidana yang diduga dilakukannya menurut KUHP.
\end{abstract}

Kata Kunci: kurator, eksekusi, pelaporan pidana 


\begin{abstract}
The curator profession is easily criminalized when carrying out his profession related to bankruptcy issues. The case that happened to Curator named Iskandar Zulkarnaen and Ali Sumali Nugroho was an example.

The problem of this research is how the position of the curator in executing bankruptcy has implications for criminal reporting and the problems and solutions faced by the curator in executing bankruptcy that have implications for criminal reporting according to the Bankruptcy and PKPU Laws. The approach method used was a normative juridical research method. This research is a descriptive analytical study. The type of data used was secondary data. Data collection methods include literature studies and documentation studies which were analyzed qualitatively.

Based on the results of the research and discussion, the position of the curator in executing bankruptcy can have implications for criminal reporting if in carrying out its duties the curator is proven not to be independent and has a conflict of interest with the debtor or creditor. This provision is regulated in Article 225 paragraph (2) Bankruptcy and PKPU Laws. The problems is Article 15 paragraph (3) and Article 234 paragraph (1) of the Bankruptcy Act and PKPU do not explain the non-independent actions that can cause a curator to be convicted. As a solution, the Bankruptcy Law and PKPU need to determine the benchmark criteria for the independence of the curator. Conclusion of this study is, as an independent legal profession, the position of the curator in executing bankruptcy is not only bound by the code of ethics of the curator profession but also bound to the Criminal Code. This means that the Criminal Procedure Code can still be applied as long as the curator fulfills the elements in a criminal act allegedly according to the Criminal Code.
\end{abstract}

Keywords: curator, execution, criminal reporting 


\section{PENDAHULUAN}

Secara kasat mata, tugas dan tanggung jawab kurator sangatlah berat. Kewenangan yang diberikan oleh undang-undang kepada kurator untuk melakukan pengurusan dan pemberesan harta pailit akan menjadi tugas berat bagi kurator jika tidak didukung dengan kemampuan individual dalam menjalankan tugas dan tanggung jawabnya.

Meskipun UU Kepailitan dan PKPU, sudah mengatur dengan jelas bagaimana kewenangan dan tugas serta tanggung jawab dari kurator, namun dalam kenyataannya melaksanakan tugas sebagai kurator tidaklah sesederhana yang digambarkan dalam undang-undang. Hambatanhambatan yang sering dihadapi, diantaranya seperti:

a. Tidak diizinkan oleh debitor pailit atau dihalang-halangi untuk memasuki kantor atau tempat kediamannya serta diancam oleh debitor atau kuasa hukumnya untuk dilaporkan secara pidana telah memasuki pekarangan secara melawan hukum (Pasal 167 KUHP);

b. Dilaporkan oleh debitur ke polisi atas dasar memasukan keterangan palsu karena menolak tagihan kreditor yang menurut debitor merupakan kreditornya (Pasal 263 KUHP);

c. Dilaporkan oleh debitor ke polisi karena melakukan pencemaran nama baik atas pengumuman kepailitan yang dilakukan oleh kurator;

d. Dilaporkan oleh debitor ke polisi atas dasar penggelapan karena telah melakukan penjualan harta pailit tanpa persetujuannya. ${ }^{1}$

Berdasarkan

contoh hambatan yang dihadapi oleh kurator tersebut, diketahui bahwa ternyata kurator dalam melakukan eksekusi budel pailit dapat berimplikasi pada adanya pelaporan secara pidana terhadap dirinya. Kasus yang menimpa Iskandar Zulkarnaen dan Ali Sumali Nugroho adalah contohya.

Iskandar Zulkarnaen dan Ali Sumali Nugroho adalah kurator dari PT. Kymco Lippo Motor Indonesia yang dilaporkan oleh salah satu kreditor konkurennya yaitu PT. Metropolitan Tirta Perdana, dengan dugaan melakukan tindak pidana memalsukan keterangan palsu ke dalam akta otentik yaitu akta jual beli harta pailit. $^{2}$ Padahal dalam pelaksanaan tugasnya, kurator telah bertindak sesuai dengan UU Kepailitan dan PKPU yang menjadi dasar kewenangannya.

Dalam sidang perkara di Pengadilan Negeri Bekasi, penuntut umum mendakwa Iskandar Zulkarnaen dan Ali Sumali Nugroho dengan Pasal 266 ayat (1) KUHP Jo. Pasal 55 ayat (1) ke (1) KUHP. Dua kurator ini didakwa telah bekerjasama memberikan keterangan palsu ke dalam akta otentik, yaitu

1 Freisy Maria Kukus, "Perlindungan Hukum Terhadap Profesi Kurator Dalam Perkara Kepailitan", Lex Privatum, Vol. III/No. 2/Apr-Jun/2015, halaman 148.

2 "Dilaporkan ke Polisi, Eks Kurator Kymco Minta Perlindungan AKPI", (Online), 29 Januari 2014, (http://www.hukumonline.com/berita/baca/lt52 e871a8ae562/dilaporkan-ke-polisi--ekskurator-kymco-minta-perlindungan-akpi, diakses tanggal 1 Mei 2018). 
menyatakan sebidang tanah SHGB Nomor 351 tidak dalam sengketa yang dicantumkan dalam Akta Jual Beli Nomor No.01/2012. Padahal, tanah tersebut dalam sengketa dan menurut penuntut umum, tindakan kurator yang menjual sebidang tanah beserta bangunan dalam suatu sengketa adalah merupakan tindak pidana, sebagaimana diatur dan diancam pidana dalam Pasal 266 ayat (1) KUHP jo Pasal 55 ayat (1) ke-1 KUHP. ${ }^{3}$

Berdasarkan

hasil

pemeriksaan di pengadilan, Majelis Hakim Pengadilan Negeri Bekasi dalam amar putusannya menyatakan Terdakwa Iskandar Zulkarnaen dan Ali Sumali Nugroho, tidak terbukti secara sah dan meyakinkan bersalah melakukan tindak pidana yang didakwakan, oleh karenanya Terdakwa harus dibebaskan dari seluruh dakwaan Penuntut Umum Pasal 266 ayat (1) KUHP jo Pasal 55 ayat (1) ke-1 KUHP. ${ }^{4}$ Majelis hakim berpendapat bahwa tindakan para kurator menjual tanah dan bangunan tersebut telah memenuhi ketentuan hukum yang berlaku. Untuk itu, Iskandar Zulkarnaen dan Ali Sumali Nugroho demi hukum tidak dapat dipersalahkan saat mereka melaksanakan tugasnya sebagai kurator.

Kasus lain yang serupa dialami oleh Kurator Jandri Onasis

3 Mahkamah Agung, "Putusan No. 1539 K/Pid/2014", (Online), 16 Maret 2015, (http:// putusan. mahkamahagung. go.id/ putusan/ downloadpdf/ bb69b14ca 0425a 5a45391bb810086452/, diakses tanggal 1 Mei 2018), halaman 7-8.

4 Ibid., halaman 9.
Siadari, yang dilaporkan oleh PT. Surabaya Agung Industri Pulp \& Kertas dengan dugaan melakukan tindak pidana turut serta membuat dan mempergunakan surat palsu. Dalam sidang perkara di Pengadilan Negeri Surabaya, Jandri Onasis Siadari didakwa melakukan tindak pidana turut serta membuat dan mempergunakan surat palsu, sebagaimana diatur dan diancam pidana dalam Pasal 263 ayat (1) jo Pasal 55 ayat (1) ke-1 KUHPidana dan Pasal 263 ayat (2) jo Pasal 55 ayat (1) ke-1 KUHP. ${ }^{5}$ Namun demikian, berdasarkan hasil pemeriksaan di pengadilan, Majelis Hakim Pengadilan Negeri Surabaya dalam amar Putusannya Nomor $\quad 939 /$ Pid.B/2014/PN. Sby,tanggal 23 Oktober 2014, menyatakan Terdakwa Jandri Onasis Siadari, tidak terbukti secara sah dan meyakinkan bersalah melakukan tindak pidana yang didakwakan, oleh karenanya Terdakwa harus dibebaskan dan dipulihkan hak-haknya dalam kemampuan, kedudukan, harkat serta martabatnya. ${ }^{6}$

Berdasarkan uraian kasus beberapa kurator yang tersangkut hukum pidana tersebut di atas, dapat diketahui bahwa ternyata profesi kurator mudah dikriminalisasi saat menjalankan profesinya terkait masalah kepengurusan harta budel pailit. Kurator seringkali harus

${ }^{5}$ Mahkamah Agung, "Putusan No. 231 K/Pid/2015", (Online), 4 Juni 2015, (https:// putusan. mahkamahagung.go.id/ putusan /downloadpdf/def1cb6211ab3 cdcd67c7df3 daf23a0c/pdf, diakses tanggal 1 Mei 2018), halaman 15.

${ }^{6}$ Ibid., halaman 16-17 
berhadapan dengan kasus hukum, termasuk tarik menarik dengan polisi saat melakukan sita terhadap budel pailit.

Dalam prinsip equality before the law memang tidak ada satupun individu yang kebal hukum, apapun profesinya ataupun jabatannya. Namun, yang membahayakan apabila terjadi bentuk-bentuk upaya "kriminalisasi" profesi yang disebabkan ketidakpahaman aparat penegak hukum, khususnya polisi, kejaksaan terhadap tugas dan kewenangan profesi kurator.

Terkait adanya pengalaman empirik terhadap hambatan dan risiko profesi kurator tersebut, maka diperlukan penelitian tentang kedudukan kurator dalam melakukan eksekusi budel pailit yang berimplikasi pada pelaporan secara pidana. Pertanyaan yang relevan diajukan disini adalah bagaimana sesungguhnya kedudukan kurator dalam melakukan eksekusi budel pailit yang berimplikasi pada pelaporan secara pidana menurut UU Kepailitan dan PKPU. Apakah kurator dalam perkara kepailitan semata-mata hanya melaksanakan amanat undang-undang, dimana menurut Pasal 50 KUHP disebutkan bahwa "barang siapa melakukan perbuatan untuk melaksanakan ketentuan undangundang tidak dipidana".

Pertanyaan lain, apakah UU Kepailitan dan PKPU yang menjadi dasar kewenangan kurator selama ini sudah cukup mengatur profesi kurator saat menjalankan profesinya yang berimplikasi pada pelaporan secara pidana. Idealnya, untuk menjamin kedudukan kurator dalam melakukan eksekusi budel pailit, maka antara UU Kepailitan dan KUHP harus dijadikan dasar pertimbangan Hakim dalam menghadapi perkara pelaporan kurator secara pidana. Untuk menjawab masalah itulah penelitian ini dilakukan.

\section{PERUMUSAN MASALAH}

Berpijak dari latar belakang penelitian sebagaimana telah diuraikan di atas, dalam penelitian ini pokok permasalahan yang akan dikaji lebih lanjut dirumuskan sebagai berikut:

1. Bagaimana kedudukan kurator dalam melakukan eksekusi budel pailit yang berimplikasi pada pelaporan secara pidana menurut Undang-Undang No. 37 Tahun 2004 tentang Kepailitan dan Penundaan Kewajiban Pembayaran Utang?

2. Bagaimana permasalahan dan solusi yang dihadapi kurator dalam melakukan eksekusi budel pailit yang berimplikasi pada pelaporan secara pidana menurut Undang-Undang No. 37 Tahun 2004 tentang Kepailitan dan Penundaan Kewajiban Pembayaran Utang?

\section{PEMBAHASAN}

A. Kedudukan Kurator Dalam Melakukan Eksekusi Budel Pailit Yang Berimplikasi Pada Pelaporan Secara Pidana Menurut Undang-Undang No. 37 Tahun 2004 tentang Kepailitan dan Penundaan Kewajiban Pembayaran Utang

Kaitannya dengan permasalahan pertama dalam penelitian ini, yaitu tentang 
bagaimana kedudukan kurator dalam melakukan eksekusi budel pailit yang berimplikasi pada pelaporan secara pidana menurut UU Kepailitan dan PKPU, peneliti akan menguraikan perkara pidana atas eksekusi budel pailit yang dilakukan oleh Kurator Iskandar Zulkarnaen dan Ali Sumali Nugroho sebagaimana dimuat dalam Putusan Mahkamah Agung No. 1539 K/Pid/2014.

Iskandar Zulkarnaen dan

Ali Sumali Nugroho adalah kurator dari PT. Kymco Lippo Motor Indonesia yang dilaporkan oleh salah satu kreditor konkurennya yaitu PT. Metropolitan Tirta Perdana, dengan dugaan melakukan tindak pidana memalsukan keterangan palsu ke dalam akta otentik yaitu akta jual beli harta pailit. ${ }^{7}$ Dalam sidang perkara di Pengadilan Negeri Bekasi, Jaksa/Penuntut Umum mendakwa Iskandar Zulkarnaen dan Ali Sumali Nugroho dengan Pasal 266 ayat (1) KUHP Jo. Pasal 55 ayat (1) ke (1) KUHP.

Iskandar Zulkarnaen dan Ali Sumali Nugroho didakwa telah bekerjasama memberikan keterangan palsu ke dalam akta otentik, yaitu menyatakan sebidang tanah SHGB No.351/ Sukaresmi tidak dalam sengketa yang dicantumkan dalam Akta Jual Beli Nomor 01/2012 (untuk selanjutnya disingkat AJB No.01/2012), tanggal 16 Januari 2012.

7 "Dilaporkan ke Polisi, Eks Kurator Kymco Minta Perlindungan AKPI", op.cit.
Padahal, tanah tersebut dalam sengketa dan menurut Jaksa/Penuntut Umum, tindakan kurator yang menjual sebidang tanah beserta bangunan dalam suatu sengketa adalah merupakan tindak pidana, sebagaimana diatur dan diancam pidana dalam Pasal 266 ayat (1) KUHP jo Pasal 55 ayat (1) ke-1 KUHP.

Berdasarkan hasil pemeriksaan di pengadilan, Majelis Hakim Pengadilan Negeri Bekasi dalam amar putusannya menyatakan Terdakwa Iskandar Zulkarnaen dan Ali Sumali Nugroho, tidak terbukti secara sah dan meyakinkan bersalah melakukan tindak pidana yang didakwakan, oleh karenanya Terdakwa harus dibebaskan dari seluruh dakwaan Jaksa/ Penuntut Umum Pasal 266 ayat (1) KUHP jo Pasal 55 ayat (1) ke-1 KUHP. Majelis Hakim berpendapat bahwa tindakan para kurator menjual tanah dan bangunan tersebut telah memenuhi ketentuan hukum yang berlaku, oelh sebab itu Iskandar Zulkarnaen dan Ali Sumali Nugroho demi hukum tidak dapat dipersalahkan saat mereka melaksanakan tugasnya sebagai kurator.

Dasar pertimbangan hukum dari Majelis Hakim Pengadilan Negeri Bekasi tentang tidak terbuktinya unsur pasal dakwaan sebagaimana yang dituntut oleh Jaksa/Penuntut Umum adalah karena Terdakwa dalam menjual budel pailit berupa 
tanah dan bangunan SHGB No.351/Sukaresmi sebagaimana AJB No.01/ 2012 tanggal 16 Januari 2012, didasarkan atas perintah undang-undang.

Selanjutnya terhadap Putusan Pengadilan Negeri Bekasi Nomor : 188/Pid.B/ 2014/PN.Bks tersebut, Jaksa/Penuntut Umum pada Kejaksaan Negeri Cikarang mengajukan kasasi kepada Mahkamah Agung pada tanggal 25 Juli 2014. Terhadap kasasi yang diajukan oleh Jaksa/ Penuntut Umum, Mahkamah Agung berpendapat bahwa alasan kasasi Penuntut Umum tidak dapat dibenarkan karena judex facti tidak salah menerapkan hukum dalam mengadili para terdakwa. Putusan Pengadilan Negeri Bekasi yang menyatakan para terdakwa tidak terbukti bersalah melakukan tindak pidana "menyuruh menempatkan keterangan palsu ke dalam suatu akta otentik tentang suatu kejadian yang kebenarannya harus dinyatakan oleh akta itu" dan karena itu membebaskan Terdakwa dari seluruh dakwaan Jaksa/Penuntut Umum dibuat berdasarkan pertimbangan hukum yang benar. Tidak terdapat cukup bukti bahwa para terdakwa melakukan perbuatan yang didakwakan Jaksa/Penuntut Umum, unsur menyuruh menempatkan keterangan palsu ke dalam suatu akta otentik tentang suatu kejadian yang kebenarannya harus dinyatakan akta tersebut tidak terpenuhi dari perbuatan para terdakwa.

Perbuatan para terdakwa selaku Tim Kurator PT. Kymco Lippo Motor Indonesia (dalam pailit) menjual budel pailit yang ada, khususnya SHGB No.351/Sukaresmi telah dilindungi oleh ketentuan hukum yang berlaku, yaitu Pasal 29 dan Pasal 31 ayat (2) UU tentang Kepailitan dan PKPU. Jika ketentuan Pasal 29 dan Pasal 31 ayat (2) tersebut dihubungkan dengan keterangan yang dibuat oleh para terdakwa, diketahui bahwa dalam menjual SHGB No.351/ Sukaresmi tanah tersebut tidak dalam sengketa, sehingga PT. Metropolitan Tirta Perdana selaku penggugat yang menggugat debitur yang perkaranya dalam upaya hukum kasasi, maka seluruh rangkaian perkara perdata yang sedang berjalan menjadi hapus.

Di samping itu, perbuatan para terdakwa juga dalam rangka melaksanakan Putusan Pengadilan No.25/Pailit/ 2010/PN.Jkt.Pst dan Penetapan No.25/Pailit/ 2010/PN.Niaga Jkt Pst tentang Pengangkatan Sita Jaminan SHGB No.351/ Sukaresmi dan Pencoretan dari Daftar Sita pada Pengadilan Negeri Bekasi serta Penetapan No.25/ Pailit/2010/PN.Niaga Jkt Pst tentang Pemberian ijin kepada Kurator untuk menjual budel pailit PT. Kymco Lippo Motor Indonesia (dalam pailit). Melaksanakan putusan dan 
penetapan pengadilan berarti sama dengan melaksanakan perintah undang-undang dalam Pasal 50 KUHP. Berdasarkan pertimbangannya tersebut, maka permohonan kasasi tersebut harus ditolak. Selanjutnya oleh karena permohonan kasasi Jaksa/ Penuntut Umum terhadap para terdakwa ditolak, maka para terdakwa tetap dibebaskan, dan biaya perkara dibebankan kepada Negara.

Perkara Kurator Iskandar Zulkarnaen dan Ali Sumali Nugroho yang dikaji dalam penelitian ini sebenarnya berawal dari perkara kepailitan, namun pada akhirnya memasuki ranah perkara pidana. Adanya perkara pidana yang menimpa Kurator Iskandar Zulkarnaen dan Ali Sumali Nugroho tersebut di atas, sebagaimana dimuat dalam Putusan Mahkamah Agung No. $1539 \mathrm{~K} / \mathrm{Pid} / 2014$, memberikan gambaran ternyata hukum pidana ada dimana-mana, termasuk hukum kepailitanpun tidak bebas dari hukum pidana. Kenyataankenyataan ini pada akhirnya kembali mempertanyakan tentang eksistensi kedudukan kurator dalam UU Kepailitan dan PKPU. Dengan kata lain, bagaimana kedudukan kurator dalam melakukan eksekusi budel pailit yang berimplikasi pada pelaporan secara pidana sebagaimana yang menimpa Kurator Iskandar Zulkarnaen dan Ali Sumali Nugroho.

Menurut UU Kepailitan dan PKPU, meskipun ditunjuk oleh pengadilan, kurator tetap diusulkan oleh pemohon pailit. Namun dalam bertugas, kurator tidak bertindak untuk kepentingan pemohon pailit melainkan untuk kepentingan budel pailit. Intinya, kurator tidak melulu lebih mendahulukan kepentingan kreditor pemohon pailit, tetapi harus adil juga terhadap debitor. Dalam konteks ini, maka kedudukan kurator dalam melaksanakan tugasnya harus independen dan tidak mempunyai benturan kepentingan dengan debitor atau kreditor. Menurut Pasal 15 ayat (3) UU Kepailitan dan PKPU, disebutkan bahwa dalam menjalankan tugasnya tersebut kurator harus independen dengan tidak mempunyai benturan kepentingan dengan debitor atau kreditor. Dalam penjelasan Pasal 15 ayat (3) UU Kepailitan dan PKPU, dikatakan bahwa yang dimaksud dengan "independen dan tidak mempunyai benturan kepentingan" adalah kelangsungan keberadaan kurator tidak tergantung pada debitur atau kreditor dan kurator tidak memiliki kepentingan ekonomis yang sama dengan kepentingan ekonomis debitur atau kreditor.

Ketentuan Pasal 15 ayat (3) UU Kepailitan dan PKPU tersebut sama dengan bunyi ketentuan Pasal 234 ayat (1) UU Kepailitan dan PKPU, yang menyebutkan bahwa Pengurus yang diangkat sebagaimana dimaksud dalam Pasal 225 
ayat (2) UU Kepailitan dan PKPU harus independen dan tidak memiliki benturan kepentingan dengan debitor atau kreditor. Kurator yang melakukan pelanggaran atas ketentuan ini dapat dikenai sanksi baik pidana maupun perdata sesuai dengan peraturan perundangundangan. Ketentuan ini diatur dalam Pasal 234 ayat (2) UU Kepailitan dan PKPU. Berdasarkan ketentuan Pasal 234 ayat (2) UU Kepailitan dan PKPU tersebut, kurator dalam melakukan eksekusi budel pailit yang terbukti tidak independen dapat berimplikasi pada adanya pelaporan secara pidana terhadap dirinya. Dengan demikian, berdasarkan ketentuan Pasal 15 ayat (3) dan Pasal 234 ayat (1) UU Kepailitan dan PKPU, diketahui bahwa kedudukan kurator dalam melakukan pengurusan dan/atau pemberesan harta pailit harus independen dan tidak mempunyai benturan kepentingan dengan debitor atau kreditor. Nilai-nilai independensi pada dasarnya berfungsi agar kurator terhindar dari penjatuhan sanksi pidana.

$\mathrm{Di}$ samping harus independen, kedudukan Kurator Iskandar Zulkarnaen dan Ali Sumali Nugroho dalam melakukan eksekusi budel pailit merupakan sebuah profesi hukum. Sebagai profesi, kedudukan Kurator Iskandar Zulkarnaen dan Ali Sumali Nugroho dalam melakukan eksekusi budel pailit terikat pada kode etik profesi kurator.
Secara garis besar, ada 3 (tiga) hal yang mendasari suatu profesi yaitu pertama, based on knowledge, dan bukan atas dasar common sense. Artinya, suatu profesi diperoleh dari adanya proses belajar keilmuan secara berkesinambungan. Kedua, memiliki skill yaitu tidak sekedar memiliki pengetahuan, namun pengetahuan tersebut harus didukung oleh suatu keahlian. Ketiga, terikat oleh adanya suatu standar moral, di mana hal ini berkaitan erat dengan nilai-nilai etika.

Sebagai sebuah profesi, maka Kurator Iskandar Zulkarnaen dan Ali Sumali Nugroho akan terikat pada etika moral. Menurut Bertens, moral juga membutuhkan hukum, sebab moral akan mengawang awang saja kalau tidak diungkapkan dan dilembagakan dalam masyarakat, seperti halnya yang terjadi dengan hukum pidana ada larangan jangan membunuh, jangan menipu, tidak saja merupakan larangan moral, tapi perbuatanperbuatan itu dilarang juga menurut hukum, dan orang yang melakukannya pun juga harus dihukum dengan tegas. Hukum juga mengatur konsekuensi-konsekuensi lebih mendetail dari prinsip-prinsip moral. ${ }^{8}$

Terkait dengan prinsip independensi, hal ini juga merupakan bagian dari suatu standar moral, yang harus

${ }^{8}$ K. Bertens, Etika (Yogyakarta: Kanisius, 2015), halaman 32. 
dijunjung tinggi oleh profesi kurator. Adapun untuk menjamin terjaganya nilai-nilai moral berhubungan erat dengan alasan etik, sehingga apabila dikemudian hari terjadi pelanggaran etik, terlebih dahulu perlu dikaji apakah pelanggaran tersebut identik dengan pelanggaran hukum, sebab hukum merupakan norma, sedangkan moral belum tentu merupakan norma hukum. Pelanggaran hukum dapat dikenai sanksi hukum namun pelanggaran etik belum tentu dikenai sanksi hukum. Independensi kurator dalam hukum kepailitan sebagaimana diatur dalam ketentuan Pasal 15 ayat (3) dan Pasal 234 ayat (1) dan (2) UU Kepailitan dan PKPU, dapat dimaknai bahwa kurator tidak boleh dan tidak dapat diintervensi oleh apapun baik oleh debitor, kreditor, maupun individu-individu lainnya di dalam lembaga kepailitan ataupun di luar lembaga kepailitan. Independen juga mencerminkan integritas seorang kurator yang didalamnya terkandung nilainilai antara lain berakhlak mulia, amanah dalam menjalankan jabatannya, dapat bersikap arif dan bijaksana dalam menghadapi realitas plural di antara kepentingan debitor dan kreditor, konsisten antara ucapan dan tanggungjawab yang diembannya, taat pada nilai dan norma baik tertulis maupun tidak tertulis dan tidak kalah penting adalah selalu berorientasi pada kepentingan terbaik bagi kepentingan harta pailit.

Selain itu, seorang kurator
yang menyatakan
kesediaannya untuk menerima tugas dan tanggungjawab mengurus harta debitor pailit berdasarkan putusan pengadilan niaga, juga harus memastikan dirinya bebas dari benturan kepentingan baik dari debitor maupun kreditor. Kurator juga memiliki kewajiban untuk menghargai setiap hak dari pihak yang terkait sehubungan dengan perbuatan hukum yang dilakukannya terhadap harta pailit, dan tidak kalah penting adalah kurator harus menjaga perilakunya jangan sampai melakukan perbuatan tercela, yaitu mengambil keuntungan dari harta pailit secara melawan hukum.

Lebih lanjut, independensi juga terkait erat dengan nilainilai objektif yang seharusnya dijunjung tinggi oleh kurator. Hal ini karena posisi kurator akan senantiasa berdiri diantara 2 (dua) kepentingan hukum yaitu kepentingan hukum debitor dan kepentingan hukum kreditur. Oleh karena itu, kurator wajib menjaga kepercayaan yang telah diberikan pengadilan, debitur maupun kreditur, memegang teguh kebenaran dan keadilan serta mentaati standar profesi dan etika sesuai isi dan semangat yang melandasinya, serta menjaga hubungan professional yang mengatur hubungan kerja dengan pihak- 
pihak terkait yaitu debitor, kreditor dan hakim pengawas. Selain itu, objektifitas juga tercermin dari sikap kurator yang mampu bertindak adil, tidak memihak dan tidak berprasangka atau bias. Kurator haruslah bebas dari kepentingan atau pengaruh pihak lain.

Meskipun hukum

kepailitan pada dasarnya merupakan ranah hukum keperdataan. Namun, ada pihak-pihak tertentu yang justru menggunakan instrumen kepailitan ini untuk mencari keuntungan bagi diri sendiri. Terhadap hal ini, KUHP telah mengatur mengenai hal-hal apa saja yang merupakan penyimpangan dari kepailitan. Apabila ada pihak yang secara sengaja melakukan perbuatan sedemikian rupa untuk menghilangkan kewajibankewajiban hukumnya melalui kepailitan atau melakukan penyelewengan untuk mengambil keuntungan dari harta pailit, maka dalam konteks ini, peran hukum pidana adalah untuk menjaga jangan sampai seseorang melakukan suatu perbuatan semata-mata hanya untuk mencari keuntungan melalui kepailitan.

Sehubungan dengan kedudukan kurator sebagai sebuah profesi hukum, maka seyogyanya tidak semua kesalahan yang dilakukan Kurator Iskandar Zulkarnaen dan Ali Sumali Nugroho perlu dipidana, sebab fungsi hukum pidana dalam kepailitan adalah hanya sebagai pengawal norma, yaitu bertujuan untuk mencegah kurator melakukan perbuatan tercela atau perbuatan pidana, sehingga sifatnya adalah ultimum remedium. Namun demikian, hukum pidana tetap dapat diberlakukan sepanjang kurator tersebut memenuhi unsurunsur dalam tindak pidana yang diduga dilakukannya menurut hukum pidana.

B. Permasalahan dan Solusi yang Dihadapi Kurator dalam Melakukan Eksekusi Budel Pailit yang Berimplikasi pada Pelaporan Secara Pidana menurut Undang-Undang No. 37 Tahun 2004 tentang Kepailitan dan Penundaan Kewajiban Pembayaran Utang

Menurut ketentuan Pasal

72 UU Kepailitan dan PKPU, kurator bertanggung jawab terhadap kesalahan atau kelalaiannya dalam melaksanakan tugas pengurusan dan/atau pemberesan yang menyebabkan kerugian terhadap harta pailit. Pengertian dan ruang lingkup kesalahan atau kelalaian disini hendaklah diberi pengertian yang jelas dan luas, sebab jika tidak tentu akan menimbulkan permasalahan bagi kurator dalam menjalankan tugasnya, dalam arti ia tidak akan dapat mengambil tindakan yang cepat karena dibayangi adanya kesalahan atau kelalaian. Oleh sebab itu, diperlukan standar 
penilaian yang dikeluarkan oleh sebuah asosiasi kurator.

Di samping itu, perlu ditekankan bahwa hendaknya tanggungjawab kurator baru dapat timbul jika dalam kesalahan baik berupa kesengajaan ataupun kelalaian itu terdapat unsur kesengajaan atau adanya kecerobohan yang dilakukan tanpa pertimbangan yang jelas. ${ }^{9}$ Hal ini mengingat dalam UU Kepailitan dan PKPU tidak menjelaskan mengenai perbuatan tidak independen apa yang dapat menyebabkan seorang kurator dipidana.

Sanksi pidana dalam Pasal 234 ayat (2) UU Kepailitan dan PKPU hanya menentukan apabila terbukti tidak independen, kurator akan dikenakan sanksi pidana sesuai dengan peraturan perundangundangan. Namun, Pasal 234 ayat (2) UU Kepailitan dan PKPU tersebut, tidak menjelaskan acuan peraturan perundang-undangan apa yang dimaksud, karena Pasal 234 ayat (2) UU Kepailitan dan PKPU hanya menyebut kata 'tidak independen', sementara tolok ukur ketidak independenan yang dimaksudkan untuk dijatuhi pidana tidak ada.

Suatu undang-undang apabila akan mengacu kepada ketentuan pidana yang lain, termasuk dalam hal ini KUHP, harus terdapat kesamaan elemen atau unsur-unsur dari norma yang diacu. Menurut

9 Sunarmi, Hukum Kepailitan (Jakarta: Softmedia, 2010), halaman 142. pendapat peneliti, persoalan mengenai independensi bukan merupakan unsur dari perbuatan pidana dan juga bukan merupakan norma hukum yang dapat dipidana. Independensi merupakan sebuah nilai, yaitu salah satu nilai yang menjadi standar moral yang masih harus diwujudkan dalam sebuah norma hukum.

Selanjutnya, apabila ketentuan Pasal 15 ayat (3) dan Pasal 234 ayat (1) dan (2) UU Kepailitan dan PKPU dihubungkan dengan teori hukum pidana, maka menjadi tidak jelas mengenai kriteria perbuatan-perbuatan tidak independen yang dapat mengakibatkan seorang kurator dijatuhi pidana. Hal ini mengingat hukum pidana memiliki batasan yang tegas untuk menjatuhkan pidana terhadap seseorang, yaitu terpenuhi 3 (tiga) unsur dalam hukum pidana, pertama adalah unsur perbuatan pidana, kedua adanya kesalahan dan pertanggungjawaban pidana serta yang ketiga adalah mengenai sanksi pidananya.

Sementara itu Pasal 15 ayat (3) dan Pasal 234 ayat (1) dan (2) dalam UU Kepailitan dan PKPU, tidak menjelaskan unsur-unsur perbuatan yang termasuk sebagai perbuatan yang tidak independen. Pemaknaan independen ini menurut peneliti sebenarnya lebih mengacu kepada nilainilai moral standar profesi yang harus dijunjung tinggi, dan bukan merupakan unsur 
tersendiri dari suatu tindak pidana. Dalam konteks ini perlu diciptakan suatu persamaan persepsi terkait dengan nilainilai independensi tersebut karena dalam UU Kepailitan dan PKPU sendiri terjadi bias penafsiran, sehingga perlu dirumuskan sebuah tolok ukur independensi, yang dapat dijadikan pedoman baik bagi kurator dalam melaksanakan tugas pemberesan terhadap harta pailit, maupun bagi aparat penegak hukum (polisi, jaksa, pengacara, dan hakim) dalam hal menangani perkara pidana yang melibatkan kurator.

Kedudukan Kurator Iskandar Zulkarnaen dan Ali Sumali Nugroho dalam melakukan eksekusi budel pailit merupakan sebuah profesi hukum. Sebagai profesi, kedudukan Kurator Iskandar Zulkarnaen dan Ali Sumali Nugroho dalam melakukan eksekusi budel pailit terikat pada kode etik profesi kurator. Oleh sebab itu, perlu adanya standar moral yang jelas tentang prinsip-prinsip independensi terkait dengan profesi kurator dalam hukum kepailitan sebagaimana diatur dalam ketentuan Pasal 15 ayat (3) dan Pasal 234 ayat (1) dan (2) UU Kepailitan dan PKPU.

Hal ini dapat dilakukan dengan cara merumuskan dan menjabarkannya dalam kode etik kurator dan UU Kepailitan dan PKPU. Adanya rumusan yang jelas tentang independensi kurator, di satu sisi dapat dijadikan pedoman bagi kurator dalam melaksanakan tugas profesinya. Sementara itu di sisi lain juga berguna bagi aparat penegak hukum khususnya Hakim, adanya rumusan yang jelas mengenai nilai-nilai independensi kurator dapat menjadi bahan pertimbangan dalam menentukan pertanggung jawaban pidana kurator, yaitu apakah perbuatan yang dilakukan memenuhi unsurunsur tindak pidana. Hal ini sekaligus sebagai perwujudan dari asas hukum equality before the law, yaitu setiap orang memiliki kedudukan yang sama dihadapan hukum.

\section{PENUTUP}

\section{A. Kesimpulan}

Berdasarkan hasil penelitian dan pembahasan, peneliti dapat simpulkan beberapa hal sebagai berikut:

1. Kedudukan kurator dalam melakukan eksekusi budel pailit dapat berimplikasi pada pelaporan secara pidana jika dalam menjalankan tugasnya kurator terbukti tidak independen dan mempunyai benturan kepentingan dengan debitor atau kreditor. Ketentuan ini diatur dalam Pasal 225 ayat (2) UU Kepailitan dan PKPU. Kurator yang melakukan pelanggaran atas ketentuan ini dapat dikenai sanksi, baik pidana maupun perdata sesuai dengan peraturan perundangundangan. Sebagai profesi hukum yang independen, kedudukan kurator dalam melakukan eksekusi budel pailit selain terikat pada kode etik 
profesi kurator juga terikat pada KUHP. Artinya, KUHP tetap dapat diberlakukan sepanjang kurator tersebut memenuhi unsur-unsur dalam tindak pidana yang diduga dilakukannya menurut KUHP.

2. Permasalahan yang dihadapi kurator dalam melakukan eksekusi budel pailit yang berimplikasi pada pelaporan secara pidana diantaranya karena UU Kepailitan dan PKPU: a. tidak mengatur secara jelas ruang lingkup kesalahan atau kelalaian kurator; b. tidak menjelaskan mengenai perbuatan tidak independen apa yang dapat menyebabkan seorang kurator dipidana; dan c. tidak adanya norma hukum dalam pencantuman sanksi pidana. Sebagai solusinya, UU Kepailitan dan PKPU: a. perlu diberi pengertian yang jelas tentang ruang lingkup kesalahan atau kelalaian kurator; b. perlu menentukan kriteria tolok ukur independensi kurator; c. perlu menyamakan unsur-unsur dari norma hukum yang ada dalam KUHP, dalam hal ini perlu diteliti hubungan antara tidak independennya seorang kurator dengan unsur kesalahan dalam hukum pidana.

\section{B. Saran}

Berdasarkan simpulan tersebut, maka peneliti mencoba memberikan saran sebagai berikut:

1. Bagi Pemerintah, UU Kepailitan dan PKPU perlu direvisi, khususnya pada Pasal 234 ayat (2). Pasal 234 ayat (2) UU
Kepailitan dan PKPU justru menimbulkan diskriminasi peraturan karena hanya ditujukan kepada kurator atau pengurus saja. Padahal, norma dan sanksi hukum pidana ditujukan kepada setiap orang yang melakukan tindak pidana, tanpa membedakan profesi, maupun status sosial seseorang.

2. Bagi aparat penegak hukum, sehubungan dengan kedudukan kurator sebagai sebuah profesi hukum, maka seyogyanya tidak semua kesalahan yang dilakukan kurator perlu dipidana, sebab fungsi hukum pidana dalam kepailitan bertujuan untuk mencegah kurator melakukan perbuatan pidana, sehingga sifatnya hanya sebagai ultimum remedium. Di samping itu, bukankah kurator dalam perkara kepailitan semata-mata hanya melaksanakan amanat undang-undang. Oleh sebab itu, diharapkan aparat penegak hukum sungguh-sungguh mengkaji kebenaran dari setiap kasus yang melibatkan kurator dalam perkara pidana.

3. Bagi masyarakat atau asosiasi kurator perlu membuat standar moral yang jelas tentang prinsip-prinsip independensi dalam kode etik kurator. Hal ini untuk memperjelas kedudukan kurator sebagai profesi hukum yang independen sebagaimana diatur dalam ketentuan Pasal 15 ayat (3) dan Pasal 234 ayat (1) dan (2) UU Kepailitan dan PKPU. Adanya rumusan yang jelas tentang independensi kurator, di satu sisi dapat 
dijadikan pedoman bagi kurator dalam melaksanakan tugas profesinya.

\section{DAFTAR PUSTAKA}

\section{a. Buku-buku}

K. Bertens. Etika. Yogyakarta: Kanisius, 2015.

Sunarmi. Hukum Kepailitan. Jakarta: Softmedia, 2010.

b. Peraturan Perundang-undangan

Kitab Undang-Undang Hukum Pidana.

Undang-Undang RI Nomor 37 Tahun 2004 tentang Kepailitan dan Penundaan Kewajiban Pembayaran Utang.

Peraturan Menteri Hukum dan Hak Asasi Manusia Republik Indonesia Nomor 18 Tahun 2013 tentang Syarat dan Tata Cara Pendaftaran Kurator dan Pengurus.

\section{c. Jurnal}

Freisy Maria Kukus. "Perlindungan Hukum Terhadap Profesi Kurator Dalam Perkara Kepailitan". Lex Privatum, Vol. III/No. 2/AprJun/2015. d. Website

"Dilaporkan ke Polisi, Eks Kurator Kymco Minta Perlindungan AKPI", (Online), 29 Januari 2014, (http:// www. hukumonline. $\mathrm{com} /$

berita/baca/lt52e871a8ae5 62/ dilaporkan-ke-polisi-eks-kurator-kymco-mintaperlindungan-akpi, diakses tanggal 1 Mei 2018).

Mahkamah Agung. "Putusan No. 1539 K/Pid/2014", (Online), 16 Maret 2015, http:// putusan. Mahkamah agung. go.id/

putusan/downloadpdf/b b69b14ca0425a5a453 91bb810086452/pdf,di akses tanggal 1 Mei 2018).

Mahkamah Agung, "Putusan No. $231 \mathrm{~K} / \mathrm{Pid} / 2015$, (Online), 4 Juni 2015, (https:// putusan.

Mahkamah agung.go.id/

putusan/downloadpdf/d ef1cb6211ab3cdcd67c 7df3daf23a0c/pdf, diakses tanggal 1 Mei 2018). 